\title{
ANALISIS GRAMATIKA ALIH KODE DARI BAHASA INGGRIS KE BAHASA INDONESIA ATAU SEBALIKNYA
}

\author{
Margana \\ Jurusan Pendidikan Bahasa Inggris \\ FBS Universitas Negeri Yogyakarta \\ Email: agana@yahoo.co.id
}

\begin{abstract}
In Indonesia, switching from one language to another language is a common phenomenon because Indonesian speakers are bilinguals. They use two or more languages, for example, Indonesian, English, or/and their own local language in a series of communication practices. With regard to the study of codeswitching, three perspectives can be used. They include pragmatic, sociolinguistic, and linguistic analyses. Of the three perspectives, analyzing codeswitching from a linguistic perspective seems to be interesting and challenging as the analysis gives an emphasis on the internal structure of the codeswitching itself. This article deals with code switching from English to Indonesian or vice-versa analyzed from grammatical aspects as part of the linguistic analysis. It aims at reviewing the grammatical rules underlying the code-swictching.
\end{abstract}

Keywords: code-switching, grammatical analysis

\section{A. PENDAHULUAN}

Dalam masyarakat multilingual, misalnya masyarakat Indonesia peralihan dari suatu bahasa ke bahasa lain atau yang dikenal alih kode (code-switching) merupakan suatu fenomena kebahasaan yang sering ditemukan dalam bebagai peristiwa komunikasi. Poplack (1980) mengatakan bahwa peristiwa alih kode tidak dapat dihindarkan ketika para penutur menguasai dua bahasa atau lebih. Peristiwa alih kode tersebut terjadi karena pihak-pihak yang terlibat dalam peristiwa komunikasi menguasai lebih dari satu bahasa yang memiliki pertalian konsep kebahasaan.

Pertalian dua konsep bahasa tersebut tergantung pada tingkat kebilingualan seseorang. Pendapat ini sejalan dengan Goh dan Silver (2004) yang mengatakan bahwa jika seorang penutur menguasai lebih dari satu bahasa, penutur tersebut memiliki beberapa pilihan ketika penutur menghubungkan antara konsep dan bentuk-bentuk leksikal. Goyvaerts dan Zembele (1992) juga mengatakan bahwa para bilingual memiliki an innate capacity yang digunakan secara otomatis untuk menyaring bentuk bahasa yang cocok dalam konteks komunikasi tertentu dengan mempertimbangkan faktor sosial, yakni partisipan, topik pembicaraan, dan seting komunikasi.

Peristiwa alih kode bukan suatu fenomena kebahasaan yang dilakukan secara serampangan. Alih kode tersebut dilatarbelakangi oleh beberapa fungsi komunikasi. Myers-Scotton dan Ury (1977) mengatakan bahwa alih kode merupakan strategi yang dinamis dalam tindak komunikasi. Alih kode dapat dijadikan sebagai strategi negosiasi dalam tindak komunikasi (Goyvaerts dan Zembele, 1992) dan alih kode berperan sebagai strategi komunikasi yang dapat digunakan untuk pengendalian keberlanjutan tindak tutur (Cook, 1991). David (2002) menambahkan bahwa alih kode dapat digunakan sebagai strategi komunikasi untuk mengatasi keterbatasan bahasa yang berakibat pada kemandegan berkomunikasi yang dilakukan oleh pihak-pihak yang terlibat dalam tindak tutur dengan berbagai macam perbedaan kemampuan berbahasa. 
Dalam berbagai kajian alih kode, para ahli bahasa banyak meneliti alih kode yang dilihat dari fungsi sosial alih kode dibandingkan analisis struktur internal yang terjadi dalam peristiwa alih kode (Yassi, 2006; Margana, 2005). Mereka cenderung mendeskripsikan fungsi-fungsi alih kode dalam peristiwa komunikasi (Flyman-Mattsson \& Burenhult, 1999; Okolo, 2002; Margana, 2005; Yassi, 2006). Hanya beberapa ahli bahasa tertarik pada kajian struktur internal alih kode (MacSwan, 1999). Jika dicermati secara seksama, kajian struktur internal alih kode lebih menarik dibandingkan kajian fungsi sosial karena kajian tersebut dimaksudkan mengupas berbagai aturan kebahasan yang melandasi peristiwa alih kode. Di samping itu, analisis struktur internal alih kode dapat mengungkap karakteristik bentuk-bentuk alih kode dengan melihat pertalian dua bahasa yang dialihkodekan dan memerikan karakteristik morfosintaksis alih kode.

Jika dilihat dari aspek linguistiknya, bentuk bahasa yang dialihkodekan dapat diidentifikasi berdasarkan fiturnya tergantung pada jenis-jenis bahasa yang digunakan. Misalnya, aturan alih kode dari bahasa Indonesia ke bahasa Jawa atau sebaliknya memiliki perbedaan aturan gramatika jika alih kode tersebut terjadi dari bahasa Inggris ke bahasa Indonesia atau sebaliknya. Peralihan bahasa Indonesia ke bahasa Jawa atau sebaliknya cenderung lebih fleksibel dibandingkan peralihan dari bahasa Inggris ke bahasa Indonesia karena bahasa Indonesia dan bahasa Jawa memiliki pertalian yang erat sebagai bahasa serumpun. Oleh karena itu, alih kode memiliki aturan-aturan gramatika tertentu bergantung pada jenis-jenis bahasa yang diaktifkan. Namun demikian, dalam hal-hal tertentu peristiwa alih kode memiliki kesamaan aturan gramatika untuk berbagai bahasa. Semua ini hanya dapat dijelaskan melalui analisis linguistik.

Sehubungan dengan analisis alih kode dari bahasa Inggris ke bahasa Indonesia atau sebaliknya, berikut disampaikan jenis-jenis aturan gramatika yang membatasi peristiwa alih kode dari bahasa Inggris ke bahasa Indonesia atau sebaliknya. Kajian aspek gramatika pada peristiwa alih kode ini sangat menarik untuk diulas karena aturan gramatika tersebut dapat dijadikan pertimbangan melakukan alih kode dari bahasa Inggris ke bahasa Indonesia atau sebaliknya ketika para dwibahasawan Indonesia-Inggris terlibat dalam peristiwa komunikasi sehingga alih kode yang dilakukan dapat tetap menjaga pertalian makna dua bahasa yang dialihkodekan.

Merujuk pada permasalahan tersebut di atas, tulisan ini membahas aturan gramatika pada peristiwa alih kode dari bahasa Inggris ke bahasa Indonesia atau sebaliknya. Pembahasan dalam artikel ini mencakup definisi alih kode, perbedaan alih kode dengan peminjaman bahasa (language borrowing), bentuk-bentuk alih kode, ulasan aturan gramatika yang terjadi pada bahasa Indonesia ke bahasa Inggris atau sebaliknya yang diikuti dengan kesimpulan. Masing-masing sub-bahasan disampaikan sebagai berikut.

\section{B. DEFINISI ALIH KODE}

Istilah alih kode memiliki makna yang beragam tergantung pada sudut pandang yang digunakan. Dalam arti luas, alih kode tidak hanya terjadi dalam masyarakat bilingual atau multilingual namun juga dapat terjadi pada masyarakat monolingual (Wardaugh, 1988). Istilah kode tidak hanya merujuk pada bahasabahasa yang berbeda tetapi merujuk pada variasi dalam suatu bahasa termasuk style atau tingkat tutur suatu bahasa. Hymes dikutip oleh Ayeomoni (2006) menyebutkan bahwa alih kode adalah pengalian dua bahasa atau lebih, pengalian berbagai variasi bahasa atau bahkan gaya berbahasa dalam suatu peristiwa komunikasi. Pengalian variasi bahasa tersebut misalnya terjadi dari bahasa Krama ke bahasa Ngoko atau sebaliknya (Soepomo, 1975) sedangkan gaya berbahasa bisa saja dari bahasa formal ke bahasa non-formal atau sebaliknya.

Dalam arti sempit, alih kode diartikan sebagai pengalihan dari suatu bahasa ke bahasa lain, misalnya dari bahasa Indonesia ke bahasa Inggris atau sebaliknya, dan bahasa-bahasa 
yang lain dalam berbagai peristiwa komunikasi baik komunikasi lisan maupun tulis. Gumperz (1982:59) mengartikan alih kode sebagai "the juxtaposition within the same speech exchange of passages of speech belonging to two different grammatical systems or subsystems". Menurutnya, unsur-unsur kebahasan yang dialihkan atau dipertukarkan memiliki keterkaitan hubungan semantik dan sintaktik dalam rentetan satu tindak tutur.

Myers-Scotton \& Jake (1997) juga mendefinisikan alih kode sebagai penggunaan dua bahasa atau lebih yang dipertukarkan satu sama lainnya dalam peristiwa komunikasi. David (2002) membedakan antara code-mixing dan codeswitching. Menurutnya, code-mixing merupakan penggunaan dua bahasa secara bergantian tetapi hanya terbatas pada penggunaan token dari bahasa sasaran, sedangkan code-switching merujuk pada penggunaan lebih dari satu bahasa yang terjadi dalam komunikasi secara keseluruhan atau dalam satu uteransi. Berbeda dengan pendapat David, Soepomo (1975) mengatakan bahwa alih kode memiliki batas-batas pengaliahan yang jelas dan memiliki fungsi komunikasi sedangkan campur kode merupakan pencampuran dua bahasa yang serampangan dan tidak memiliki fungsi yang jelas. Sejalan dengan pendapat Soepomo (1975), Ferguson dalam Romaine (1995) mengatakan bahwa peristiwa alih kode terjadi pada masyarakat diglosik yang mempersyaratkan minimal dua bahasa atau dua variasi bahasa yang secara bersama-sama digunakan untuk pemenuhan fungsi-fungsi komunikasi tertentu dengan mempertimbangkan ketepatan pemilihan kata yang disesuaikan dengan konteks sosial.

Merujuk pada definisi-definisi tersebut di atas, dalam makalah ini penulis menggunakan definisi alih kode dalam arti sempit, yakni pengalihan dari satu bahasa ke bahasa lain dalam peristiwa komunikasi. Pengalihan antar dua bahasa tersebut dilandasi oleh pemenuhan fungsi-fungsi tertentu dalam tindak komunikasi. Dalam hal ini, penulis mengkaji peristiwa alih kode dari bahasa Inggris ke bahasa Indonesia atau seebaliknya yang dianalisis dengan menngunakan kajian linguistik.

\section{PERBEDAAN ALIH KODE DAN KATA PINJAMAN}

Istilah alih kode memiliki kimiripan makna dengan istilah kata pinjaman atau yang dikenal dengan language borrowing. Kedua istilah tersebut terkadang dipahami secara tumpang tindih. Untuk meminimasi ketumpang-tindihan pemaknaan istilah tersebut, Haugen dikutip oleh Romaine (1995) menawarkan beberapa kriteria diantaranya adalah penyatuan, yakni seberapa jauh leksikon tersebut telah diintegrasikan ke dalam bahasa peminjam. Jika unsur kebahasaan yang dipertukarkan belum diintegrasikan ke dalam bahasa yang digunakan, maka peristiwa tersebut dinamakan alih kode. Sebaliknya, jika unsur kebahasaan yang pertukarkan telah menjadi bagian dari salah satu leksikon bahasa tersebut dengan berbagai penyesuaian baik secara fonologis dan/atau morfologis, peristiwa tersebut dinamakan peminjaman. Crystal (1985) mengatakan bahwa asimilasi merupakan salah satu indikator pembeda antara alih kode dan peminjaman. Menurut dia, peminjaman merujuk pada pengadopsian bentuk-bentuk kebahasaan seperti unit leksikal, unit gramatika, afiks derivasi, dan system bunyi dari bahasa donor ke bahasa peminjam. Sebaliknya, alih kode tidak hanya terbatas pada penyisipan unsur-unsur kebahasaan, tetapi juga berupa pengalihan klausa atau/dan kalimat.

Bentuk proses yang dipinjam dari bahasa Inggris process merupakan bentuk pinjaman dari bahasa Inggris ke bahasa Indonesia yang telah mengalami perubahan secara fonologis maupun pengejaan. Bentuk investasi (bahasa Indonesia) berasal dari bentuk investment (bahasa Inggris) dan bentuk dan efektivitas (bahasa Indonesia) berasal dari bentuk effectiveness (bahasa Inggris). Kedua bentuk leksikon tersebut telah menjadi bagian dari bahasa Indonesia sebagai peminjam dengan penyesuaian secara fonologis dan morfologis. Berikut juga disampaikan contohcontoh bentuk-bentuk peminjaman dari bahasa 
Inggris ke bahasa Indonesia yang diperoleh dari surat kabar.

(1) Sedangkan jika menginvestasikan dananya di instrumen jangka panjang seperti obligasi, mereka akan terkena pajak (Kompas, 20 Sept. 2007).

(2) Anwar menjelaskan, modus penyelundupan yang dilakukan eksportir adalah dengan memalsukan dokumen (Kompas, 21 Desember 2007).

(3) Sikap hidup berkorban untuk orang banyak atau altruisme bermakna terbalik dengan egoisme (Kampus, 21 Desember 2007).

Bentuk-bentuk yang digarisbawahi tersebut di atas merupakan contoh bentukbentuk peminjaman dari bahasa Inggris ke bahasa Indonesia yang telah diintegrasikan ke dalam bahasa peminjam melalui proses penyesuain fonologis dan morfologis. Bentukbentuk tersebut telah menjadi bagian dari leksikon bahasa Indonesia dan digunakan secara mapan dan berkelanjutan dalam proses komunikasi tulis maupun lisan. Namun demikian, kiteria penyesuaian fonologis dan morfologis dari bahasa donor ke dalam bahasa peminjam banyak dipertanyakan oleh sebagian ahli bahasa karena penyisipan sebuah unsur bahasa yang berupa kata merupakan bentuk integrasi secara morfologis (Pfaff, 1979; Myers-Scotton, 1993). Kriteria yang ditawarkan untuk membedakan antara alih kode dan kata pinjaman adalah dengan cara mengidentifikasi a base language yang tampak dalam suatu wacana yang menggunakan dua bahasa.

Berikut disampaikan contoh bentukbentuk alih kode dari bahasa Indonesia ke bahasa Inggris atau sebaliknya.

(4) Itu trik mereka untuk mengurangi nervous. (Indosiar: Superstar, 20-2.2008)

(5) Maya dan Sofi, wow incredible or bagus sekali. (Indosiar: Superstar, 20-2-2008)

(6) Saya ingi melihat anda sharing berdua. (Indosiar: Super Mama, 25-12-2007)

(7) Celana dan jaket mama tidak matching. (Indosiar: Super Mama, 25-12-2007)
(8) I think kamu terlalu serius. (Indosiar: Super Star, 25-1-2008)

(9) What does Tia want to say? Tia mau bilang apa? (Micro-teaching, 12-3-2008)

Data (4), (5), (6), dan (7) menunjukkan peristiwa alih kode dari bahasa Indonesia ke bahasa Inggris. Pada data tersebut, bahasa Indonesia sebagai bahasa yang disisipi (base language), sedangkan bahasa Inggris sebagai bahasa yang disisipkan (embedded language). Data (8) dan (9) merupakan alih kode dari bahasa Inggris ke bahasa Indonesia. Pada data tersebut, bahasa Inggris sebagai base language sedangkan bahasa Indonesia adalah bahasa yang dipertukarkan. Data (8) merupakan contoh alih kode berbentuk klausa sedangkan Data (9) adalah alih kode berbentuk kalimat.

Pemahaman perbedaan makna alih kode dan peminjaman (borrowing) tersebut di atas dapat digunakan sebagai rujukan dalam menganalisa data alih kode sehingga analis data lebih akurat dan tajam. Di samping itu, kesalahan pemilahan data dapat diminimasi semaksimal mungkin.

\section{JENIS-JENIS ALIH KODE}

Berdasrkan bentuknya, alih kode dapat dibedakan menjadi beberapa jenis tergantung pada sudut pandang yang digunakan. Wardhaugh (1988) menawarkan dua jenis alih kode, yakni alih kode situasional dan metaporik. Alih kode situasional merujuk pada pengalihan bahasa satu ke bahasa lain tanpa terjadi perubahan topik pembicaraan. Sebaliknya, alih kode metaporik diartikan sebagai pengalihan suatu bahasa ke bahasa lain dalam tindak komunikasi yang diikuti dengan perubahan topik. Berbeda dengan istilah yang ditawarkan Wardhaugh (1988), Blom dan Gumperz (1972) menggunakan istilah alih kode transaksional dan metaporik atau alih kode nonsituasional vs situasional. Alih kode transaksional merujuk pada perpindahan dari satu bahasa ke bahasa lain yang dikendalikan oleh komponen peristiwa tindak tutur seperti topik dan penutur. Alih kode metaporik 
berkaitan dengan efek komunikasi yang ingin disampaikan oleh penutur.

Dilihat dari unsur bahasa yang dipertukarkan, Romaine (1995) membedakan alih kode menjadi tiga jenis, yakni alih kode intrasentensial, alih kode intersentensial, dan tag-switching. Alih kode intrasentensial dimaknai sebagai penyisisipan suatu unsur kebahasaan yang berupa kata, frasa, atau klausa bawahan dalam suatu bahasa matriks. Penyisipan unsur kebahasaan tersebut terjadi dalam batas klausa atau kalimat. Berikut disajikan contoh alih kode instrasentensial.

(10) Ngomongin tentang love, malam ini, kita kedatangan lovely woman, Patricia. (TransTV-7, Empat Mata, 25 Des. 2008)

(11) By the way, katanya akhir tahun ini sedang ada proyek buat anak, ya? (TransTV-7, Empat Mata, 25 Des. 2008)

(12) I absolutely know that kamu berdua kurang persiapan. (Indosiar: Super Star, 25-1-2008)

Data (10) menunjukkan adanya peristiwa alih kode, yakni penyisipan bentuk kata love, dan bentuk frasa nomina lovely woman di dalam batas kalimat. Data (11) juga terjadi peristiwa penyisipan bentuk frasa preposisi by the way. Selanjutnya, Data (12) merupakan contoh penyisipan bentuk klausa bawahan dalam suatu kalimat. Jenis alih kode tersebut disebut alih kode intrasentensial.

Jenis alih kode yang kedua adalah alih kode intersentensial. Jenis ini dimaknai peristiwa pengalihan unsur bahasa dari bahasa matriks ke bahasa non-matriks (embedded language) yang terjadi antar kalimat. Berikut disajikan contoh alih kode intersentensial.

(13) What did you do with the girl? Apa yang kamu lakukan terhadap gadis itu? (Microteaching, 12-3-2008)

(14) Teacher:Tarno, number 3.

Student: Seven.

Teacher : Coba diulangi lagi.

(Micro-teaching, 12-3-2008)
(15) Teacher : True or False, ya? Kamu jawabannya benar atau salah?

(Micro-teaching, 12-3-2008)

Data (13), (14), dan (15) merupakan jenis alih kode intersentensial karena pengalihan tersebut terjadi di luar batas kalimat. Pada Data (15), terdapat jenis alih kode tagswitching, yakni penyisipan bentuk, ya, khan, you know, dan sebagainya dalam batas kalimat.

Terkait dengan jenis-jenis alih kode tersebut di atas, penulis membedakan alih kode menjadi dua jenis, yakni alih kode intrasentensial dan intersentensial. Jenis alih kode tag-switching dapat dikategorikan ke dalam jenis alih kode intrasentensial karena penyisipan tersebut tidak melebihi batas kalimat dalam suatu wacana. Pendapat ini sejalan dengan Poplack (1980) yang membedakan alih kode menjadi dua jenis, yakni alih kode intrasentensial (switching within sentence boundary) dan intersentensial (switching across sentence boundary).

Di antara dua jenis alih kode tersebut, jenis alih kode intersentensial memiliki frekuensi pengalihan yang lebih tinggi dibandingkan dengan intrasentensial dalam peristiwa komunikasi (Poplack, 1980). Penemuan ini berbeda dengan penemuan yang dilakukan oleh Berk-Seligson (1985) yang mengatakan bahwa $63 \%$ pengalihan unsur bahasa terjadi pada kategori intrasentensial. Terjadinya perbedaan tersebut mungkin disebabkan oleh perbedaan objek bahasa yang diteliti atau perbedaan metodologi yang digunakan dalam penentuan kategori alih kode. Selanjutnya, pada jenis alih kode intrasentensial, peristiwa pengalihan unsur kebahasaan seringkali terjadi pada pada tingkat konstituen utama, yakni antara frasa nomina dan frasa kerja. Poplack (1980) juga mengdokumentasikan bahwa kata benda memiliki frekuensi pengalihan yang paling tinggi dibandingkan jenis kata lain karena kata benda memiliki kelenturan dalam konstruksi sintaktis. 


\section{E. ASPEK GRAMATIKA DALAM PERISTIWAALIH KODE}

Peristiwa alih kode setidaknya dipengaruhi oleh faktor sosial, yakni seting, topik, dan tingkat kemampuan penutur terhadap bahasa yang diaktifkan. Di samping faktorfaktor tersebut, para ahli bahasa (Sankoff \& Poplack, 1980; Joshi, 1985; MacSwan, 1997) mengatakan bahwa peristiwa alih kode juga dipengaruhi oleh faktor linguistik. Romaine (1995) menyebutkan bahwa alih kode merupakan percampuran unsur kebahasaan yang terjadi pada dua bahasa yang berbeda ke dalam satu pertalian gramatika. Oleh karena itu, pertalian dua unsur kebahasaan yang berbeda tersebut dapat dikaji dengan menggunakan perspektif linguistik, yakni menganalisa peristiwa alih kode dengan titik penekanan pada pembatas gramatika dan unsur-unsur kebahasaan yang dipertukarkan.

Sankoff \& Poplack (1980) mengajukan dua pembatas terjadinya alih kode. Prinsip pertama 'free morpheme constraint' mengatakan bahwa alih kode tidak mungkin terjadi di antara morfem terikat dan morfem bebas kecuali bentuk morfem tersebut sudah diintegrasikan secara fonologis ke dalam morfem bahasa matriks. Bentuk-bentuk alih kode berikut tidak mungkin terjadi dalam peristiwa komunikasi dari bahasa Inggris ke bahasa Indonesia atau sebaliknya.

(16) *Bekti dilove oleh Avanza.

(17) *Mr. Sukarno teachkan struktur 3.

(18) * The books were dipinjamed by Lia.

(19) * The bukus are mine.

Prinsip kedua 'the equvalence constraint' menyebutkan bahwa alih kode dapat dilakukan jika pengalihan unsur kebahasaan dua bahasa yang diaktifkan tidak melanggar kaidah sintaktis dua bahasa yang pertukarkan sebagaimana disampaikan dalam data berikut.

(20) I am sorry, sir, I do not membawa *English buku $m y$ ".

(21) *English buku saya tertinggal di my belajar table.

Data (20) dan (22) tidak dijumpai dalam peristiwa komunikasi karena penyisipan unsur-unsur kebahasaan tersebut bertentangan dengan kaidah kedua bahasa tersebut. Misalnya, bentuk *English buku my menyalahi kaidah pembentukan frasa bahasa Inggris maupun bahasa Indonesia. Hal yang sama juga terjadi pada bentuk *English buku saya dan *my belajar table.

Joshi (1985) menawarkan dua kaidah terjadinya alih kode, yakni asymmetry dan closed class items. Kaidah pertama menyebutkan bahwa peristiwa aihkode terjadi dari bahasa yang dominan (matrix language) ke bahasa yang tidak dominan (embedded language). Kaidah kedua mengatakan bahwa klas kata tertutup, misalnya artikel/determiner, kata kerja bantu, kata ganti kepunyaan, kata depan, dsb tidak lazim dipertukarkan. Berikut disampaikan contoh-contoh alih kode yang tidak lazim ditemui dalam peristiwa komunikasi yang melibatkan bahasa Inggris dan bahasa Indonesia.

(22) * The buah-buahan is mahal sekali.

(23) * Did anda belajar bahasa Inggris last night?

(24) *Catatan his is not clear.

(25) *You may have the same topic dengan your friend.

Bentuk-bentuk yang digarisbawahi tersebut di atas tidak ditemukan dalam peristiwa komunikasi karena bentuk-bentuk tersebut termasuk bentuk kata tertutup. Kaidah kedua yang disampaikan oleh Joshi (1985) memiliki kesamaan dengan kaidah functional head constraint model yang disampaikan oleh Belazi, dkk (1994).

Selain dua prinsip yang mengikat terjadinya alih kode tersebut di atas, menawarkan prinsip hubungan ketergantungan atau keterkaitan secara gramatika. Menurut prinsip ini, alih kode hanya mungkin terjadi jika unsur-unsur kebahasaan yang dipertukarkan tidak memiliki hubungan interdependensi. Dengan kata lain, jika unsur-unsur kebahasaan secara leksikal memiliki hubungan keterpautan satu sama lainnya, unsur kebahasaan dari bahasa non-matriks tidak dapat disisipkan ke bahasa matriks. 
Myers-Scotton (1993) menawarkan Matrix Language Frame (MLF) Model yang terdiri atas (1) the morpheme order principle dan (2) the system morpheme principle, (3) blocking hipothesis, dan (4) the EL Island Trigger Hipothesis. Prinsip pertama mengatakan bahwa alih kode dibatasi oleh hubungan sintaktis dasar yang ada dalam unsurunsur bahasa yang diaktifkan. Prinsip kedua mengatakan bahwa bahasa matriks menentukan kehadiran unsur-unsur bahasa yang akan disisipkan selama unsur bahasa tersebut memiliki pertautan makna dan fungsi dengan unsur bahasa matriks. Prinsip ketiga menyebutkan bahwa terjadi pemblokiran unsur-unsur bahasa yang disisipkan jika unsur tersebut tidak memiliki pertalian makna dan fungsi dengan unsur bahasa matriks. Model ketiga menyebutkan bahwa jika morfem bahasa yang disisipkan bertentangan dengan prinsip 1, 2, atau 3, unsur tersebut dapat dijadikan sebagai unsur penentu untuk kemunculan unsur bahasa yang disisipkan. Keempat prinsip tersebut dapat dijadikan pertimbangan bagi para dwibahasawan ketika mereka melakukan alih kode dari bahasa Inggris ke bahasa Indonesia atau sebaliknya.

Perlu dicatat bahwa kaidah-kaidah tersebut di atas belum tentu dapat mengikat semua bahasa yang ada karena setiap bahasa memiliki kaidah gramatika tertentu yang mungkin berbeda satu sama lainnya. Namun demikian, kaidah-kaidah tersebut dapat digunakan sebagai analisis alih kode dari perspektiflinguistik.

\section{G. PENUTUP}

Merujuk pada pembahasan tersebut di atas, disimpulkan bahwa alih kode merupakan fenomena kebahasaan yang lazim terjadi dalam masyarakat bilingualisme, yang mengaktifkan dua bahasa atau lebih dalam tindak komunikasi. Peristiwa alih kode tidak dilakukan secara serampangan melainkan dilakukan dengan pola, arah, dan fungsi yang jelas. Kejelasan pola, arah dan fungsi tersebut dapat dikaji dari perspektif linguistik dan non-linguistik.
Pengkajian alih kode dari perspektif linguistik menarik untuk dilakukan. Kemenarikan kajian ini terletak pada keterpautan dua konsep makna dan fungsi serta aturan gramatika dalam peristiwa alih kode. Aturan gramatika yang melandasi terjadinya alih kode sebagaimana diuraikan di atas dapat dijadikan pertimbangan bagi dwibahasawan dalam melakukan alih kode dari bahasa Inggris ke bahasa Indonesia atau sebaliknya ketika mereka terlibat dalam peristiwa komunikasi sehingga alih kode yang dilakukan tetap menjaga pertalian makna dua bahasa yang dialihkodekan.

\section{DAFTAR PUSTAKA}

Ayeomoni, M.O. 2006. Code-switching and code-mixing: Style of language use in Childhood in Yoruba speech community. Nordic Journal of African Studies 15(1): 90-99.

Belazi, H., M., Edward J. Rubin, and Almeida J. Toribio. 1994. Code-switching and Xbar theory: the functional head constraint. Linguistic Inquiry 25: 221237.

Berk-Seligson, S. 1986. Linguistic constraints on intra-sentential code-switching: A study of Spanish/Hebrew bilingualism. Language in Society, 15 (3), 313-348.

Blom dan Gumperz. 1972. "Social meaning in linguistic structures: code-switching in Norway", in J.J. Gumperz, D. Hymes (eds). Direction in Sociolinguistics. New York: Holt. Reinhart and Winston.

Cook, V. 1991. Second language learning and language teaching. Melbourne: Edward Arnold/ Hodder Headline Group.

Cook, V. 2001. Using the first language in the classroom? Canadian Modern Language Review, 57, 402-423.

Crystal, D. 1985. A dictionary of linguistics and phonetics. Oxford: Blackwell.

David, M. K. 2002. Communicative Strategies in Malaysian Sindhi Homes. In David, 
M. K. (ed.), Methodological Issues in Language Maintenance and Language Shift Studies. Frankfurt: Peter Lang, 59-70.

Di Sciullo, A. M., Muysken, P., \& Singh, R. 1986. Government and code-mixing. Journal of Linguistics, 22, 1-24.

Gumperz, J. J. 1982. Conversational codeswitching. In J. J. Gumperz (Ed.), Discourse Strategies. Cambridge: Cambridge University Press.

Flyman-Mattsson, A \& Burenhult, N. 1999. Code-switching in second language teaching of French. Working Papers, 47, 59-72.

Goyvaerts, L.G. and Z. T. Zembele. 1992. "Codeswitching in Bukavu". Multilingual and Multicultural Development.13: N.1-2.

Goh, C. C. M. \& Silver, R. E 2004. Language Acquisition and Development: A Teacher's Guide. Singapore: Longman.

Gumperz, J. J., \& Hernández-Chavez, E. 1975. Bilingualism, bidialectalism, and classroom interaction. In C. Cazden, V. P. John, \& D. Hymes (Ed.), Functions of language in the classroom (pp. 84-107). New York: Teachers College Press.

Joshi, Aravind. 1985. "Processing of Sentences with Intrasentential Codeswitching". In MacSwan J. A Minimalist Approach to Intrasentential Code Switching: Spanish-Nahualt Bilingualism in Central Mexico. Colifornia: University of Colifornia.

MacSwan, J. 1997. A minimalist approach to intra-sentential code switching: Spanish-Nahuatl bilingualism in central Mexico. Doctorial Dissertation. University of California, Los Angeles. Retrieved on August 30,

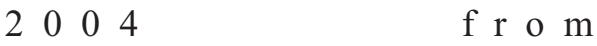
http://www.publica.asu.edu/ macswa n/bilingualism.pdf.

MacSwan, J. 1999. A Minimalist Approach to Intra-sentential Code Switching. New York: Garland Publishing.
Margana. 2005. Codeswitching Practised by English Teachers and Students of Junior High Schools of Yogyakarta. Yogyakarta: Thesis S2.

Myers-Scotton, C. 1993. Common and uncommon ground: Social and structural factors in code switching. Language in Society, 22, 475-503.

Myers-Scotton, C. 1993. Social motivations for codeswitching: Evidence from Africa. Oxford: Oxford University Press.

Myers-Scotton, C. 1993. Duelling languages: grammatical structures in codeswitching. Oxford: Clarendon Press.

Myers-Scotton, C. and Ury. W. 1977. Bilingual strategies: The social functions of codeswitching. International Journal of Sociology of Language, 13, 5-20.

Myers-Scotton, C., \& Jake, J.L. 1997. Codeswitching and compromise strategies: Implications for lexical structure. International Journal of Bilingualism, 1 ,

Okolo, Bertram A. 2002. Coversational Roles abd Social Functions of CodeSwitching among Igbo Bilinguals, Jornal of Asian and African Studies, No. 64

Pfaff, C.W. 1979. Constraints on language mixing: Intra-sentential codeswitching and borrowing in Spanish/English. Language 55, 291318.

Poedjosoedarmo, Soepomo. 1975. "Kode dan Alihkode", dalam Widyapurwa 15.

Poplack, S. 1980. Sometimes I'll start a sentence in Spanish y termino en Español: Toward a typology of codeswitching. Linguistics, 18, 581-618.

Romaine, S. 1995. Bilingualism (Second edition). Oxford, UK: Basil Blackwell Ltd.

Sankoff, D., \& Poplack, S. 1980. A formal grammar for code-switching. New York: Language Policy Task Force, Center for Puerto Rican Studies.

Analisis Gramatika Alih Kode dari Bahasa Inggris ke Bahasa Indonesia ... (Margana) 
Wardahugh, Ronald. (1988). An Introduction to Sociolinguistics. New York: Basil Blackwell.

Yassi, Abdul Hakim. 2006. Speech Vareity of Elite People in Makasar: Forms and Social Functions of IndonesianEnglish Code Switching diunduh dari http://www.unhas.ac.id/sastraarab/Jurnal/2006_Nov/Inggris_Hakim pada tanggal 6 November 2009. 